\title{
The influence of price on rice production in Sierra Leone
}

\author{
Alhaji Mohamed Hamza Conteh*, Xiangbin Yan, Foday Pinka Sankoh \\ Management Science and Engineering, School of Management, Harbin Institute of Technology, Harbin, China; \\ *Corresponding Author: hadjmannc90@yahoo.com
}

Received 10 March 2012; revised 23 April 2012; accepted 14 May 2012

\section{ABSTRACT}

Rice is the main staple food of the vast majority of Sierra Leoneans, eaten on a daily basis by almost every household in the country. Rice is the most important food crop widely grown by farmers across the country. Although much attention is now focused on rice production through the small holder commercialization programme (SHCP), less attention has been given to investigating the constraints faced by rice producers in the country. Also, as food insecurity continues to be a major development problem across the country, thereby undermining people's health, productivity, and often their very survival; this study contributes to efforts to overcome the development challenges posed by food insecurity necessarily begin with accurate assessment of influential factors that con- strained the production of the staple food, rice. The main objective of this study is therefore to analysis the factors that influence rice production in the country, and specifically examine the relationship between rice production and the price of rice as sold in the domestic market. The study used a log linear model with the quantity of rice produced as the dependent variable and the price of domestic rice, quantity of rice imported and price of imported rice as explanatory. Findings indicated that, domestic rice is more expensive than imported rice per ton, and this underscores the argument that, rice importation is undermining domestic rice production as a viable income generating activity. Also, almost all the people in the capital city which hosts about $70 \%$ of the total population of country prefer eating imported rice, since it is free from stones and other impurities. However, In order to control price and still increase rice production, the government should be able to purchase the rice from the farmers and then sell this rice to private retailers.

Keywords: Sierra Leone; Food Security; Rice Production; Econometric Model Specification; Price of Domestic Rice

\section{INTRODUCTION}

For the past decades, rice has taken an outstanding position as an intentional crop for food security and economic development of nations of the world. According to [1] FAO (2000) classified the crop as the most important food depended upon by over 50 percent of the world population for about 80 percent of their food need. Due to the growing importance of the crop and increasing challenges of the attainment of food security, it has been estimated that annual rice production needs to increase from 586 million metric tons (mt) in 2001 to meet the projected global demand of about 756 million metric tons by 2030 [2] quoted [3]. Recent global trend in the rice industry shows that, there is a growing import demand for the commodity in Africa, as evidence from pressure on the world supply and the steady increase in the world price of the commodity in the last five years [4]. Africa has become a giant player in international rice markets, accounting for 32\% of global imports in 2006, at a record level of 9 million tones that year. Africa's emergence as a big rice importer is explained by the fact that during the last decade rice has become the most rapidly growing food source in sub-Saharan [5]. Indeed, due to population growth (4\% per annum), rising incomes and a shift in consumer preferences in favor of rice, especially in urban areas [6], the relative growth in demand for rice is faster in this region than anywhere in the world [7]. This is occurring throughout the sub regions of sub-Saharan Africa (SSA). In recent years (2001-2005), rice production has been expanding at the rate of $6 \%$ per annum, with $70 \%$ of the production increase due mainly to land expansion and only $30 \%$ being attributed to an increase in productivity [8] quote [9]. Much of the ex- 
pansion has been in the rainfed systems, particularly the two major ecosystems that make up $78 \%$ of rice land in West and Central Africa (WCA): the upland and rainfed lowland systems [10]. Nonetheless, demand for rice in WCA has far outstripped the local production [11]. Reference [12] quoted Osiriz (CIRAD’s Observatory of International Rice Statistics) Africa cultivated about 9 million hectares of rice in 2006 and a production, which surpassed 20 million tons for the first time, is expected to increase by $7 \%$ per year in future. In West Africa, where the rice sector is by far the most important in SSA, the situation is particularly critical. Despite the upward trends in international and domestic rice consumption is increasing at a rate of $8 \%$ per annum, surpassing domestic rice production growth rates of $6 \%$ per annum. The production-consumption gap in this region is being filled with by imports, valued at over US \$1.4 billion per year [13]. The share of imports in consumption rose from an average of $43 \%$ from 1991 to 2000, to an average 57\% by 2002-2004 [14]. The Food and Agriculture Organization of the United Nations [15] estimated that current rice imports into the West and Central Africa sub-regions had grown to more than 6 million tons costing over $\$ 1$ billion in scarce foreign exchange each year. The cost of importing rice therefore remains a heavy burden on trade balances in the region.

Rice has been gathered, consumed, and cultivated by many people worldwide for more than 10,000 years [16], longer than any other crop. The total area under rice cultivation is globally estimated to be $150,000,000$ ha with annual production averaging 500,000,000 metric tons [17]. This represents $29 \%$ of the total output of grain crops worldwide, [18]. By 2004, more than half of the world's population depended on rice as its major daily source of calories and protein, each consuming from 100 to $200 \mathrm{~kg}$ of rice per year. On the other hand, the Green Revolution of the $1960 / 70$ s, saved the world from a catastrophe of eminent food shortage, it was the drastic increase in rice production that answered the then desperate food demands of the world's growing populations. Today, more than two billion people in Asia alone derive $80 \%$ of their calorie intake from rice. According to projected population growth [19], the number of people living on rice worldwide is expected to reach 3.5 billion in 2025. The importance of the crop in food security and socioeconomic stability is therefore self-evident. The importance of rice in the international and national economies compelled the development of resolution 2/2001 of the Conference of the Food and Agriculture Organization of the UN to declare the year 2004 as the International Year of Rice. Rice is a staple food in Sierra Leone and constitutes a major part of the diet in the country. During the past three decades the crop has seen consistent increases in demand and its growing importance is evident in the strategic food security planning policies of Sierra Leone. Although few countries have attained self-sufficiency in rice production, rice demand exceeds production and large quantities of rice are imported to meet demand at a huge cost in hard currency in Sierra Leone. Rice is very well established in the agriculture and diets of Sierra Leone. Sierra Leoneans consume an estimated 530,000 tons of rice annually, or more than 200 kg per capita.

Rice lands cover some 180,000 ha and annual production is about 200,000 tons. Most rice is produced in upland systems, which account for $64 \%$ of total national rice area. Inland valley swamp systems are the second major ecosystem, covering another 26\%. Only a small portion, less than $5 \%$, of the inland valley swamp rice area has been developed, permitting partial water control. Domestic rice production has stagnated, and Sierra Leone now meets only $70 \%$ of its total requirements. As the country recovers from civil strife, sustainable rice production will depend on greater support for input supply and output marketing, and development of lowland rice production.

The Government of Sierra Leone has prioritized agriculture as the most important sector of the national economy around which it is focusing its development efforts. This is not surprising because agriculture contributes $50 \%$ of GDP and employs over $75 \%$ of the national work force. Seventy-four percent of the land area of the country, covering 5.4 million hectares, is suitable for cultivation. This area comprises 4.3 million hectares of upland and 1.1 million of lowland. Over $90 \%$ of the lowland area is arable and suited to rice cultivation. These include the very fertile inland valley swamps found in all regions of the country, the less fertile saucer shaped bolilands in the northern region, the deep flooding riverain grasslands in the southern region and the tidal mangrove swamps of the North-western coastal belt. Rice is also grown on the upland areas, throughout the country, employing the environmentally damaging slash and burn shifting cultivation system which is being discouraged. About twothirds of the population lives in rural communities deriving their livelihoods from agricultural pursuits. And yet, annually, the country imports nearly $40 \%$ of the national staple food, rice.

In Sierra Leone, Rice is the main staple food of the vast majority of Sierra Leoneans; eaten on a daily basis by almost every household in the country. Rice is the most important food crop widely grown by farmers across the country; and beside rice; cassava, sweet potato, maize, vegetables, millet, palm oil and groundnut are other important food crops in Sierra Leone. There is also a huge potential for all types of commercial fruit production. To illustrate, according to currently available data, over the last three years rice production and imports have 
increased simultaneously (Figure 1).

Subsistence rice farming is the dominant agricultural practice undertaken by nearly $90 \%$ of farm families. Although farmers do cultivate other crops such as cassava, sweet potatoes and vegetables, rice is clearly the dominant crop cultivated in the country.

Sierra Leone requires about 530,000 $\mathrm{mt}$ of milled rice to meet the consumption needs of the population annually. National Paddy Rice Production was projected at $524,000 \mathrm{mt}$ in 2006 and 638,000 $\mathrm{mt}$ in 2007 [20]. The level of rice self-sufficiency rose from 57.45 percent in 2002, to 69 percent in 2005 and then to 71 percent in 2007. The remainder must be imported at increasingly expensive prices in the current situation of high prices for food including rice. International nominal prices of all major food commodities reached, in the first three months of 2008, their highest level in nearly 50 years, while prices in real terms in nearly 30 years. The prices of rice, the main staple food in Sierra Leone has seen a steady increase by more than $50 \%$ on average in the entire country.

The rising of food prices in Sierra Leone since January 2008 to date is a very serious threat to the livelihoods of majority of Sierra Leoneans. Most affected by this recent food price inflation, are the low-income urban and periurban households, who are largely dependent on the market to access their food requirements. Smallholder food deficit farmers are also among the worst affected by the continued increases in prices of the staple food, causing among them, high or extreme levels of food insecurity. Female and elderly headed households are the most destitute. The promotion of domestic rice production is therefore a key element in the strategies for improving food security, stimulate economic growth and increase rural income. Effort to support rice production programmes is the only solution to pull the country out of the worsening rice situation and reverse the present declining trend in food self-sufficiency. Although rice is the staple of Sierra Leoneans, yet the annual per capita consumption of rice (104 kg) is considered to be amongst the highest in sub Saharan Africa [21].

Rice production in Sierra Leone is in the hands of small-scale farmers who produce barely enough for home consumption with little or none for the market. During the 2004/05 cropping season 56 percent of the households cultivated less than 1 ha of farm land while only 44 percent cultivated 1 ha and more. Rice field area per household ranged from 0.25 ha to 5.5 ha with an average of 1.06 ha. [22]. The small scale farmers in Sierra Leone are generally resource poor with only the hoe, axe and cutlass as the main implements while labour is mainly supplied by family members thereby severely limiting their scale of production. On the other hand, the widespread use of unimproved varieties, limited use of fertilizer, coupled with unimproved cultural practices adversely affects rice production.

Since Sierra Leone's independence, agricultural development policy has been focused on the achievement of rice self-sufficiency among other objectives. Major interventions in the sector have included both direct government participation (mechanical rice cultivation in the riverain grasslands around Gbundapi and Torma Bum, and the bolilands in the Bombali and Tonkolili Districts) and indirectly, through the donor-funded integrated agricultural/rural development projects, which covered over $80 \%$ of the country in the 1970 s and 1980s. All of these interventions targeted small-holder farmers, who constitute approximately $90 \%$ of the farmer population. The performances of the various interventions were generally disappointing and during the last two decades, the overall performance of the agricultural sector has been poor.

There are major challenges to overcome, if Sierra Leone has to eradicate extreme hunger. These include:

Food insecurity remains a threat especially in rural areas of Sierra Leone, because of the low production, low income, poor rural infrastructure (road networks), transportation and access to markets.

Production technology is still subsistence-level and

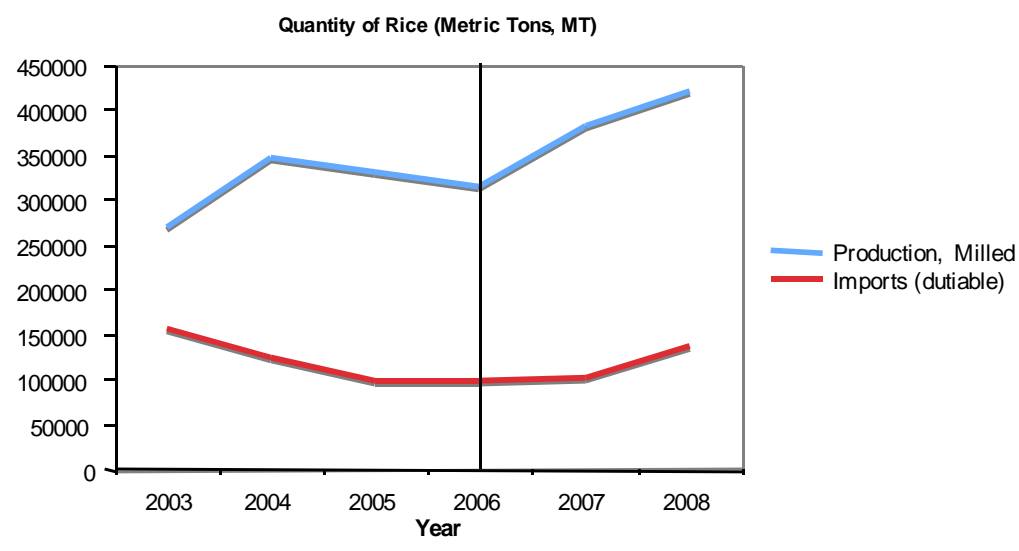

Figure 1. Domestic rice production and imports (Metric Tons, MT), 2003-2008. 
requires transition to commercial agriculture.

The majority of the population has limited knowledge of nutrition, translating into poor dieting practices and the high incidence of under-weight and poor growth in children.

Service delivery for production (research and modern inputs etc.) is weak.

The lack of a comprehensive agricultural database and an early warning information system pose difficulties for forecasting climatic conditions, pest and disease threats.

A recent rice production survey has shown that the ordinary consumers of rice in the country could not feel the impact of local rice production because of their preference for imported varieties of rice from Asia and other countries. Added that while the current level of rice production in the country had increased tremendously but what people need is to adjust their preference in respect of locally grown food stuffs.

This Study therefore presents a new avenue for evaluating the rice production in the country, based on the data collected by The Planning, Evaluation, Monitoring and Statistics Division (PEMSD). Greater accuracy at the country level will provide the necessary foundations for enhancing rice production and hence overcoming food insecurity in the country.

\section{RESEARCH QUESTIONS}

The study therefore aims to answer the following research question:

How can domestic price of rice influence rice production?

\section{OBJECTIVES OF THE STUDY}

The main objective of this study is to analyze the constraints facing rice production in the country using econometric model and specifically:

To examine the relationship between rice production and the price of rice as sold in the domestic market.

\section{MATERIALS AND METHODOLOGY}

This section highlights the materials and methodology used in the study.

Econometric Model Specification

The prime considerations in designing the model were to incorporate all important demand-side, supply-side and policy variables and keep it straight and effective in explaining the causes of fluctuation in rice output over the period 2001-2010. The quantity of domestic rice produce is the dependent variable and the explanatory variables include price of domestic rice, price of imported rice and quantity of imported rice. These variables are central to understanding the fluctuations in rice production in the country.
From the theoretical and empirical discussion, the rice production function for this study is specified in the log form as follows:

$$
L n Q_{t}=\alpha+\beta_{1} \ln P_{t}+\beta_{2} \ln Q M_{t}+\beta_{3} \ln P M_{t}+U_{t}
$$

where:

$Q_{t}=$ quantity of domestic rice produced

$P_{t}=$ price of domestic rice in Leones (Le)

$Q M_{t}=$ quantity of rice imported into the country

$P M_{t}=$ price of imported rice in Leones (Le)

$U_{t}=$ white nose error term.

\subsection{A Prior Signs of the Variables}

The price of domestic rice is expected to have a positive relationship with the quantity of rice produced, this is because the price serves as a signal to producers for a high demand and hence encourages producers to produce more rice to take advantage of the high price and hence earn higher income.

The coefficient of the quantity of rice imported (QM) is expected to have a negative sign as the two commodeties are substitutes; which means that the more rice produced, the less rice that is expected to be imported and verse versa.

The coefficient of the price of imported rice is expected to have a positive sign since the higher the price of the imported rice, the lower the quantity consumed and hence the lower the quantity imported. The lower the quantity of imported rice the higher demand for domestic rice, and hence the higher the quantity of domestic rice produced to meet with the higher demand.

\subsection{Stationarity and Non-Stationarity}

The importance of the concept of stationarity arises from the fact that virtually the entire body of statistical estimation theory is based on asymptotic convergence theorems i.e. the weak law of large numbers, which assumes that all data series are stationary. In real life, however, non-stationarity is common in macroeconomic time series such as income, consumption, money supply, prices and trade data. Treating non-stationary series as if they were stationary will bias the Ordinary Least Squares (OLS) and thus result in misleading economic analysis. For example, the model will systematically fail to predict outcomes and can also lead to the problem of spurious (misleading) regressions where R-squared is approximating unity; $t$ and F-statistics look significant and valid. In essence, the problem lies with the presence of spurious regression that arises where the regression of nonstationary series, which are known to be unrelated, indicates that the series are correlated. Hence, there is often a problem of falsely concluding that a relationship exists between two unrelated non-stationary series. This problem 
generally increases with the sample size, and is not normally solved by including a deterministic time trend as one of the explanatory variables in order to induce stationarity. In order to avoid the spurious regression problem, with its related non-stationary pattern of the variables, stationalrity tests were carried out on the variable. Once stationarity or non-stationarity of the variable was established, non-stationary variable will be differenced as a way of bringing non-stationary series to stationarity.

\subsection{Unit Root Testing}

Having established the vector of variables of interest we considered the order of integration (or stationary) of each series using the Augmented Dickey Fuller (ADF) unit root tests. This is a " $t$ " test that relies on rejecting the hypothesis that the series is a random walk in favour of stationarity. The ADF test has high predictive value, more especially, when the series follows an autoregressive (AR) process, which is plausible for many of the less frequent data sets such as the annual series being used in this study. The ADF Test formula is given as:

$$
\Delta Y_{t}=\gamma Y_{t-1}+\beta t+\varepsilon_{t}
$$

The ADF Test is:

$\mathrm{H}_{0}: \quad \gamma=0$; that is, $Y_{t}$ has units roots-not stationary;

$\mathrm{H}_{1}: \quad \gamma \neq 0$; that is, $Y_{t}$ has no units roots-stationary.

The unit root testing results obtained using the ADF tests are treated as reliable for this study, and hence it would seem reasonable to proceed only with these results given the data limitation faced by the study. The Eviews statistical package was used to obtain the results.

\section{RESULTS AND DISCUSSIONS}

This section analyses the data and the results of the log regression.

\subsection{Descriptive Analysis}

Rice is the major staple for majority of Sierra Leoneans, and as such rice production is a major agricultural activity. However, rice is produced by mainly small-scale farmers working on at a subsistence level. As part of its effort to achieve food self-sufficiency drive, the Sierra Leone government does give assistance to farmers in the form of improve seeds, fertilizers and some farming tools in order to aid the production process. Table 1 gives a descriptive analysis of the variables under consideration in this study.

Table 1 shows that the average rice production for the 10 -year period is 762731.7 metric tons, while the maximum registered in 2010 is 1,570,094. On the other hand, the average retail price per tone is Le1, 868,872, while the average retail price of imported rice is Le1, 507895.62. This shows that the domestic rice is more expensive
Table 1. Descriptive statistics of the variables under study.

\begin{tabular}{ccccc}
\hline Statistics & $\begin{array}{c}\text { Local Rice } \\
\text { Production } \\
(\mathrm{Mt})\end{array}$ & $\begin{array}{c}\text { Retail Price } \\
\text { of Local } \\
\text { Rice (Le) }\end{array}$ & $\begin{array}{c}\text { Rice } \\
\text { Imported } \\
(\mathrm{Mt})\end{array}$ & $\begin{array}{c}\text { Retail Price of } \\
\text { Imported Rice } \\
\text { (Le) }\end{array}$ \\
\hline Mean & 762731.7 & $1,868,872$ & 138.5951 & 1507895.616 \\
Maximum & $1,570,094$ & $3,165,021$ & 193.146 & 2715749.76 \\
Minimum & 310,620 & 867129.2 & 96.4 & 724320.99 \\
\hline
\end{tabular}

than the imported rice per ton; and this underscores the argument that rice importation is undermining domestic efforts to promote domestic production as a viable income generating activity. Although the quantity imported is relatively small (138.6 metric tons per year), it is capable of feeding the urban population in the country.

\subsection{General Model Results}

This model is run on the log of the data obtained for each variable without checking for time series properties of the variables themselves and it is specified below:

$$
\ln Q_{t}=\alpha+\beta_{1} \ln P_{t}+\beta_{2} \ln Q M_{t}+\beta_{3} \ln P M_{t}+U_{t}
$$

The results presented in Table 2 show R-squared has a value 0.9811 , which means that $98.1 \%$ of variations in the dependent variable $\left(\log Q_{t}\right)$ are explained by variations in the explanatory variables. The Adjusted Rsquared, which captures the relational effect of an additional variable on the dependent variable, also has high value of $96.6 \%$. This shows that the model was a pretty good fit. In addition, the F-Statistic, which tests for joint significance of the explanatory variables significant at the $1 \%$ level. This mean that the explanatory variables are jointly significant in determining the variations in the dependent variable (the quantity of rice produced); that the joint changes of the explanatory variables significantly affect the movements of the quantity of rice production in the country.

Table 2 shows that only log of quantity of rice imported is significant at 5\% level; the other two explanatory Variables are not significantly related with the dependent variable. Thus suggests model specification problem, this could mean that the model is suffering from multi-co linearity problem as suggested by the DW Statistics of 2.7.

Figure 2 of the quantities and prices of domestic and imported rice is shown.

\section{THE FINAL LOG MODEL}

As already mentioned, it became clear that the model was suffering from multicolinearity problems; as a result, the retail price of imported price was dropped from the model since it was found to have a high correlation with the retail price of the domestic rice. The model is found to have improved considerably and the final model is 
Table 2. Level regression analysis results.

Dependent Variable: LPROD

Method: Least Squares

Date: 02/25/12 Time: 17:22

Included Observations: 10

\begin{tabular}{|c|c|c|c|c|}
\hline Variable & Coefficient & Std. Error & t-Statistic & Prob. \\
\hline LFERT & 0.257294 & 0.158032 & 1.628115 & 0.1644 \\
\hline LRLOCAL & 0.181175 & 0.774904 & 0.233804 & 0.8244 \\
\hline LQUNTM & 0.594381 & 0.166699 & 3.565592 & 0.0161 \\
\hline LRFPRICE & 0.826584 & 0.658929 & 1.254436 & 0.2651 \\
\hline $\mathrm{C}$ & -4.65804 & 2.512376 & -1.85404 & 0.1229 \\
\hline ed & & & & 0.981104 \\
\hline R-squared & & & & 0.965988 \\
\hline ic & & & & 64.90273 \\
\hline statistic) & & & & 0.000169 \\
\hline Watson stat & & & & 2.720592 \\
\hline
\end{tabular}

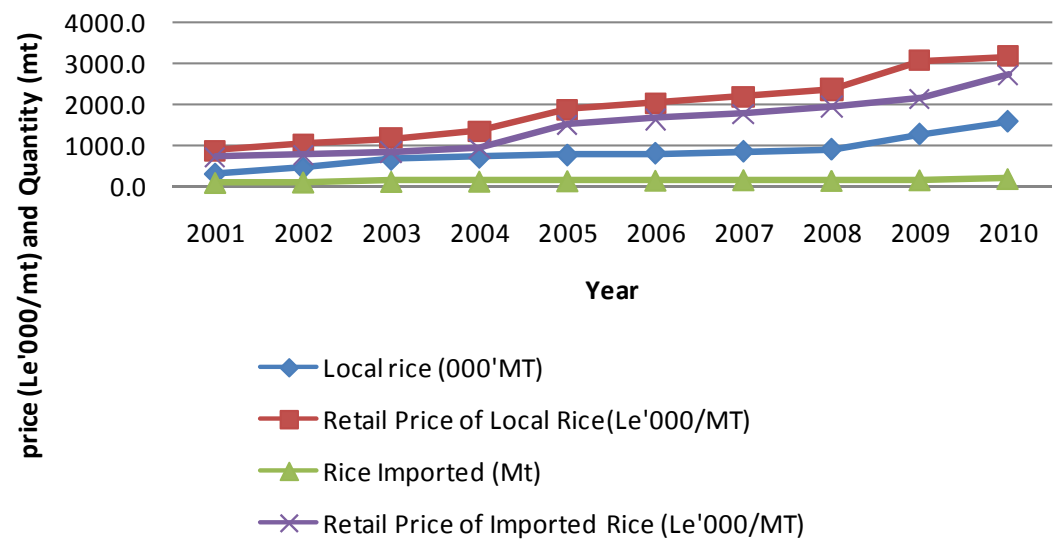

Figure 2. The quantities and prices of domestic and imported rice (2001-2010).

shown in Eq.2.

$$
\ln Q_{t}=\alpha+\beta_{1} \ln P_{t}+\beta_{2} \ln Q M_{t}+U_{t}
$$

The model was estimated in its level as stationarity tests show that log variables were stationary in their level. In a situation of structural breaks and data gaps like the one we are faced with as a country recovering from war, log models are usually appropriate since they narrow down the data gaps and also smoothens the series. It is for this purpose that the log model is being estimate for rice production in Sierra Leone.

The results of the model are shown in Table 2 .

The results (Table 3) show that R-square is 0.975, which means that $97.5 \%$ of variations in rice production. F-statistic is significant at $1 \%$, which means that the explanatory variables are jointly significant in determining the variations in rice production in Sierra Leone. This underscores that fact that the model is very good-fit. The $\mathrm{D}-\mathrm{W}$ statistic (2.06) shows that the problem of multi- collinarity does not significantly distort the results of the model.

The domestic price of local rice in the domestic market has the expected positive sign, which is also very significant at the $1 \%$ level. This indicates that that there is a positive and significant relationship between the quantity of rice produced and the domestic price of rice in the market. This means that a $1 \%$ increase in the local price of domestic rice will result in a $114 \%$ increase in rice production in the country. The result clearly underscores the role of price as an incentive for increased supply of agricultural produce in the market. Like any other producer, the price is a very good indicator of the expected revenue due; and since 2005 when the government launched the "tractorization" programme, there has been increase awareness among farmers about the need for farmers to produce and to market their produce. Agriculture nowadays is regarded as an active commercial business activity, which should be able to generate profit 
Table 3. Level regression analysis results.

\begin{tabular}{|c|c|c|c|c|}
\hline \multicolumn{5}{|c|}{ Dependent Variable: LPROD } \\
\hline \multicolumn{5}{|c|}{ Method: Least Squares } \\
\hline \multicolumn{5}{|c|}{ Date: 02/25/12 Time: 17:18 } \\
\hline \multicolumn{5}{|c|}{ Included Observations: 10} \\
\hline Variable & Coefficient & Std. Error & t-Statistic & Prob. \\
\hline LFERT & 0.119766 & 0.119134 & 1.005298 & 0.3536 \\
\hline LRLOCAL & 1.14041 & 0.131359 & 8.681636 & 0.0001 \\
\hline LQUNTM & 0.69422 & 0.153314 & 4.528096 & 0.004 \\
\hline $\mathrm{C}$ & -6.76711 & 1.954098 & -3.46304 & 0.0134 \\
\hline \multicolumn{4}{|l|}{ R-squared } & 0.975157 \\
\hline \multicolumn{4}{|c|}{ Adjusted R-squared } & 0.962736 \\
\hline \multicolumn{4}{|l|}{ F-statistic } & 78.50704 \\
\hline \multicolumn{4}{|c|}{ Prob (F-statistic) } & 0.000033 \\
\hline \multicolumn{4}{|c|}{ Durbin-Watson stat (D-W stat) } & 2.057461 \\
\hline
\end{tabular}

for producers/investors.

The log of quantity of imported rice variable has the unexpected positive sign, and it is significant at the $1 \%$ level. Although the paper expected domestic rice production to have an inverse relationship with imported rice, since the two commodities should essentially be substitute, yet the result confirms what has been the argument sometime now that domestic production of rice goes mainly to feed the rural populations and not the urban populations. It is a fact in this country that most urban dwellers hardly consume domestic rice. The reason for this is that domestic rice is normally not processed and destined and packaged in a form required by urban dwellers; urban dwellers require rice that is free from stones and does not take a long time to be washed and cooked. Although much effort has been done in trying to de-stone rice, only imported rice does meet the quality of rice required by urban populations. As a result, increase domestic production of rice does not cause a decline in the quantity/volume of rice imported into the country, since urban populations depend on the imported rice for their consumption.

\section{CONCLUSION AND POLICY IMPLICATIONS}

Rice is traded among the Mano River Union countries (Sierra Leone, Guinea, Liberia and Cote d'Ivoire). There is an apparent net flow of rice from Sierra Leone to the neighboring countries. Periodically, when rice prices are high particularly due to outside forces, there is the tendency for restrictions to be put on the exportation of rice by State authorities. It is clear that this measure has had very little, and if any, only temporary effects on rice prices in the country. As a result this study has confirmed the fears of many analysts that rice importation will con- tinue despite the increase in domestic rice production due to the issue of smuggling and poor processing of the domestic rice to meet the requirement of urban dwellers.

Agriculture is the mainstay of the rural populations and the most dominant of the country's economic sectors followed by mining. The crop sector dominates the agricultural sector while rice is predominant in the crop sector. The domestic retail price is found to be a good signal to farmers for increase demand, which in turn encourages farmers to produce more rice. Virtually all farmers in Sierra Leone grow rice which is the staple food and considered as a political crop in the country. Rice development therefore does not only provide food for the populace, it provides employment for a considerable number of farmers, saves valuable foreign exchange and impacts on the overall economy of the country.

It is clear that Sierra Leone has a comparative advantage in domestic production of rice for import substitution i.e. to supply its domestic market.

Agriculture is an important aspect of the economic life of most people in Sub-Saharan Africa, as the economies are mostly agrarian economies. In West Africa, rice production forms an integral part of agricultural activities, and in Sierra Leone, the cultivation of rice is seen as not only a way of feeding the population but also a possible way improving rural income and foreign exchange earnings. That is why the main focus of the recently launched small holder commercialization programme (SHCP), among many others, is to enhance the produce processing, storage and access to markets. Price of rice being an economic indicator would influence the decisions of farmers to produce more. The study has shown that the price of domestic rice is higher than imported rice, which suggests the following:

That there is possible market for domestic rice production.

That there could be possible supply bottlenecks limiting the free movement of rice from production arrears to milling centers to storage facilities and to the markets.

The study will therefore be handy in assisting agricultural researchers in investigating the rice supply bottlenecks as well as developing high-yielding varieties of rice to boost production in the country. Since domestic rice is found be less competitive, rice researchers would need to focus on improving yield productivity and access to both domestic and international markets. As agricultural researchers need feedback from the market and users, the study will inform researchers on the market demand situation of rice in the country, which in turn should help shape research proposals.

Therefore policy emphasis on attainment of self sufficiency in rice production appears to be economically justified. There is need for the government to re-establish the produce marketing boards to assist farmers to access 
inputs and to sell their output. Furthermore, In order to control price and still increase rice production, the government should be able to purchase the rice from the farmers and then sell this rice to private retailers.

\section{REFERENCES}

[1] Saka, J.O. and Lawal, B.O. (2009) Determinants of adoption and productivity of improved rice varieties in southwestern Nigeria. African Journal of Biotechnology, 8, 4923-4932

[2] Food and Agriculture Organization (2002) FAO rice international. FAO, Rome.

[3] Keuneman, E.A. (2006) Improved rice production in a changing environment: From concept to practice. International Rice Commission Newsletter, 5, 2.

[4] Food and Agriculture Organization (2006) Rice Market Monitor. FAO, Rome.

[5] Awotide, B., Awoyemi, T. and Diagne, A. (2012) Impact of access to subsidized certified improved rice seed on income: Evidence from rice farming households in Nigeria.

http://www.inter-reseaux.org/IMG/pdf/SSRN-id1982848. pdf

[6] Seck, P.A., Diagne, A. and Mohanty, S. (2012) Crops that feed the world 7: Rice. Food Security, 4, 7-24.

[7] African Rice Centre (WARDA) (2005-2006) Annual report. WARDA, Cotonou.

[8] Dontsop, P.M., Nguezet, D.A. and Okoruwa, V.O. (2011) Impact of improved rice technology on income and poverty among rice farming household in Nigeria: A local average treatment.

http://www.csae.ox.ac.uk/conferences/2011-EDiA/papers/ 247-DontsopNguezet.pdf

[9] Fagade, S.O. (2000). Yield gaps and productivity decline in rice production in Nigeria. Expert Consultation on Yield Gap and Production Decline in Rice, Rome, 5-7 September 2000, 15.

[10] Nguezet, D., Martin, P. and Diagne, A. (2010) Estimation of actual and potential adoption rates and determinants of improved rice variety among rice farmers in Nigeria: The case of NERICAs.

[11] Somado, E.A. and Guei, R.G. (2008) Over view: Rice in Africa. Africa Rice Center, Bouaké.

[12] Somado, E.A. and Guei, R.G. (2007) Over view: Rice in Africa a compendium. Africa Rice Center, Bouaké.

[13] Somado, E.A. and Guei, R.G. (2008) Over view: The new rice for Africa 2008. Rice in Africa. Africa Rice Center, Bouaké.

[14] African Rice Center (WARDA) (2004) Rice trends in subSaharan Africa. 3rd Edition, WARDA, Cotonou, 2005.

[15] Food and Agriculture Organization (2006) Over view: Rice in Africa a compendium. Africa Rice 2008. Africa Rice Center, Bouaké.

[16] Kenmore, P. (2003) Sustainable rice production, food security and enhanced livelihoods. In: Mew, T.W., Ed., Rice Science: Innovations and Impact for Livelihood, International Rice Research Institute, Los Banos, 27-34.

[17] Tsuboi, T. (2005) WARDA-NERICA rice workshop, WARDA, Cotonou.

[18] Xu, K.D. and Shen, G.F. (2003) Promoting Chinese rice production through innovative science and technology. Proceedings of the International Rice Research Conference, Beijing, 16-19 September 2002, 11-18.

[19] Song, J. (2003) Sustaining food security rice science: Innovations and impact for livelihood. http://books.google.com/

[20] Davies, S. (2009) Livelihood in the farming communities: A paper presented for workshop. How to improve farming communities in Sierra Leone. Unpublished Discussion paper, Freetown.

[21] Dingle, R. (1984) Swamp rice development, Sierra Leone: Observations and recommendations. Unpublished paper. FAO, Rome.

[22] Government of Sierra Leone (GOSL) (2004) Sierra Leone poverty reduction strategy paper (PRSP): Agricultural sector. Unpublished Discussion Paper, Freetown. 